\title{
Drivers of the accumulation of mercury and organochlorine pollutants in Mediterranean lean fish and dietary significance
}

\author{
Eva Junqué ${ }^{\mathrm{a}}$, Mercè Garí ${ }^{\mathrm{a}, \mathrm{b}}$, Rosa Maria Llull ${ }^{\mathrm{c}}$, Joan O. Grimalt ${ }^{\mathrm{a}, *}$ \\ a Department of Environmental Chemistry, Institute of Environmental Assessment and Water Research (IDAEA-CSIC), Barcelona, Catalonia, Spain \\ ${ }^{\mathrm{b}}$ Department of Earth and Ocean Dynamics, Universitat de Barcelona (UB), Barcelona, Catalonia, Spain \\ c General Direction of Public Health and Consumption, Ministry of Health, Family and Social Welfare, Government of the Balearic Islands, Palma, Mallorca, Spain
}

\section{H I G H L I G H T S}

- $40 \%$ of Mediterranean lean fish had $\mathrm{Hg}$ concentrations above EU recommended values.

- The levels of organochlorine compounds in all specimens were below the EU threshold.

- Hg levels were correlated with specimen weight but the trend was species dependent.

- The organochlorine compound concentrations were not correlated with specimen weight.

- Mediterranean populations feeding on fish have higher EWI for $\mathrm{Hg}$ than the EFSA PTWIs.

\section{A R T I C L E I N F O}

\section{Article history:}

Received 10 January 2018

Received in revised form 9 March 2018

Accepted 27 March 2018

Available online 5 April 2018

Editor: D. Barcelo

\section{Keywords}

Mediterranean lean fish

Mercury

Organochlorine pollutants

Provisional tolerable weekly intakes

Trophic level and pollutant accumulation Balearic Islands
G R A P H I C A L A B S T R A C T
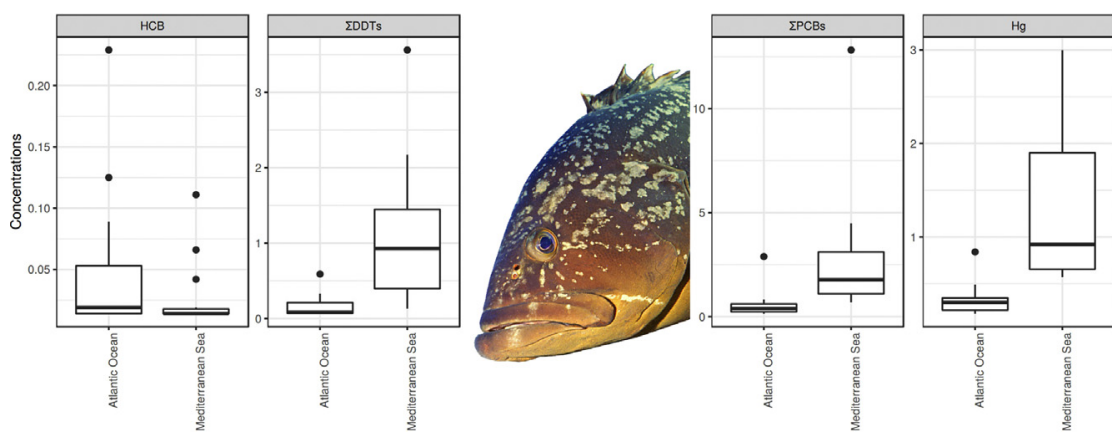

\begin{abstract}
A B S T R A C T
An integrated assessment of lean fish of commercial value as $\mathrm{Hg}$ and organochlorine compound source into the population of the Balearic Islands were reported. Dependences between pollutant concentrations, trophic level, fish species, specimen weight and physical-chemical properties were evaluated.

$\mathrm{Hg}$ and total DDTs showed highest variability between fish species whereas PCBs and HCB displayed more constant median values. The organochlorine compounds found in highest concentrations were those with highest hydrophobicity, consistently with their higher bioaccumulation potential. These pollutant concentrations were higher in Mediterranean than Atlantic fish. Higher median total DDT and PCBs concentrations were also observed in the third than the second trophic level species. The observed concentrations were below the threshold recommended by the EU for human consumption ( $75 \mathrm{ng} / \mathrm{g}$ wet weight).

The Hg concentrations were higher in Mediterranean than Atlantic fish, with average values of $1.5 \mu \mathrm{g} / \mathrm{g}$ ww and $0.43 \mu \mathrm{g} / \mathrm{g}$ ww, respectively. Forty-one percent of the specimens from the Mediterranean and 25\% of dusky grouper specimens from the Atlantic Ocean showed $\mathrm{Hg}$ concentrations above the EU recommended limits for human consumption, either $0.5 \mu \mathrm{g} / \mathrm{g}$ ww or $1 \mu \mathrm{g} / \mathrm{g}$ ww.

In the third trophic level, a significant dependence between median $\mathrm{Hg}$ concentrations and weight of each studied species was observed, which remained significant in specimen weight correlations. Independent species correlations of $\mathrm{Hg}$ concentrations vs individual weight generally showed higher concentrations at higher weight. Weight/size of the individuals was therefore an important factor for $\mathrm{Hg}$ accumulation but the trend was modulated by a species effect.
\end{abstract}

\footnotetext{
* Corresponding author.

E-mail address: joan.grimalt@idaea.csic.es. (J.O. Grimalt).
} 
Extrapolation of the observed $\mathrm{Hg}$ concentrations in Mediterranean fish to Provisional Tolerable Weekly Intakes (PTWIs) showed higher intakes than the thresholds recommended by EFSA for adults and children, $110 \%$ and $140 \%$, respectively. The estimated PTWIs for MeHg corresponded to $310 \%$ and $400 \%$ of the recommended threshold values. The PTWI values for organochlorine compounds were lower than those recommended.

(c) 2018 Elsevier B.V. All rights reserved.

\section{Introduction}

Fish consumption has been associated to human accumulation of mercury (Hg) and organochlorine pesticides (Llop et al., 2010; Gascon et al., 2012, 2013; Garí et al., 2013; Vizcaino et al., 2014; Costa et al., 2016; Bravo et al., 2017). Despite their different origin and structure, OCs and $\mathrm{Hg}$ share common properties such as (I) strong chemical stability and environmental persistence, (II) bioconcentration in living organisms and biomagnification through the food chain due to their hydrophobic character and (III) toxicity for humans and wild animals. Methylmercury is a more toxic form than the original metal whose human intake is also attributed to fish and seafood (Calatayud et al., 2012; Garí et al., 2013; Perello et al., 2014; Cano-Sancho et al., 2015; Obeid et al., 2017).

Human exposure to environmental concentrations of organochlorine compounds with high number of chlorine substituents has been associated to diverse deleterious effects, e.g. hexachlorobenzene (HCB) to attention deficit hyperactivity syndrome (Ribas-Fitó et al., 2007), alteration of thyroid hormones (Álvarez-Pedrerol et al., 2008; Sala et al., 2001), overweight (Smink et al., 2008) and thyroid cancer (Grimalt et al., 1994), DDE to increases of asthma (Ribas-Fito et al., 2006; Sunyer et al., 2006), alteration of thyroid hormones (Álvarez-Pedrerol et al., 2008) and urinary coproporphyrins (Sunyer et al., 2008), DDT to decreases of cognitive skills (Ribas-Fito et al., 2006; Morales et al., 2008), oncogene mutation (Porta et al., 1999), and polychlorobiphenyls (PCBs) to overweight (Valvi et al., 2012), oncogene mutation (Porta et al., 1999; Howsam et al., 2004), impaired liver metabolism (Sala et al., 2001) and neuropsychological development (Forns et al., 2012; Gascon et al., 2013) among others.

On the other hand, methylmercury (MeHg) targets the nervous system, especially during the children developmental stage (Grandjean et al., 1997; World Health Organization - International Programme on Chemical Safety (WHO-IPCS), 1990). Contamination episodes in Japan showed irreversible neurological damage upon exposure to this compound (Harada, 1995) and neurotoxicity and neurodevelopmental risk among children exposed to low or moderate $\mathrm{Hg}$ levels have been investigated (Karagas et al., 2012).

Accordingly, the production and use of OCs and $\mathrm{Hg}$ has been restricted and/or banned in many countries. However, these contaminants are still found in the environmental compartments (Arellano et al., 2011; Lamborg et al., 2014), foodstuff (Martí-Cid et al., 2010; Olmedo et al., 2013) and human tissues (Vizcaino et al., 2014; Garí et al., 2013).

Even though there are many sources of human exposure to these pollutants, it is well-known that ingestion is the main route (representing $>90 \%$ of the total exposure) and, especially, through consumption of fatty food such as fish (Xu et al., 2017 and Vázquez et al., 2015). Until very recently, fish consumption recommendations for vulnerable population groups, such as infants and pregnant women, have focussed on certain big, migratory and oily fish species (EFSA, 2012, 2015; AESA, 2006). However, since $\mathrm{Hg}$ is primarily associated with muscle tissue rather than fat, predatory but non-migratory fish species, e.g. lean fish, may also accumulate this compound. This is particularly relevant for carnivorous species feeding at the top of the food chain which increase the concentrations of these pollutants by bioaccumulation. To date, few studies have assessed the potential role of predatory but non-migratory fish species regularly consumed by general and infant populations as sources of organochlorine compounds and $\mathrm{Hg}$.
This concern is high in island populations for being typically high fish consumers, particularly from local markets. These populations are prone to accumulate high levels of these pollutants (Grandjean et al., 1997; Myers et al., 2000; Murata et al., 2002). Previous studies on newborns and preschool children from Mediterranean populations have shown high Hg concentrations in blood and hair (Freire et al., 2010; Garí et al., 2013; Llop et al., 2014). They evidence the need for assessment of the role of different fish species in human exposure to these pollutants.

In this sense, we performed two preliminary studies on the intake of these compounds, one on $\mathrm{Hg}$ in Mediterranean lean fish and seafood (Llull et al., 2017) and another on a diet evaluation of the population from Menorca (Junqué et al., 2017). Now, an integrated assessment of lean fish species of commercial value as sources of both Hg and organochlorine compounds in islander populations is reported. The Balearic Islands are adequate reference sites for their location in the western Mediterranean. Thus, most of the fish specimens were obtained from fishermen of these islands. The study has been extended to fish specimens from Tunisia and Egypt. Samples from the Atlantic Ocean, in front of Senegal and Mauritania, two big fishery areas due to upwelling, have also been collected and examined for comparison.

To acquire further data on the possible human health risks of fish consumption, this study examined the weekly intakes of both children and adults and comparison with the Provisional Tolerable Weekly Intakes (PTWIs) established by the European Food and Safety Authority (EFSA, 2012). The study is also aimed to ascertain whether the concentrations of Total $\mathrm{Hg}$ are compliant with the maximum values in fishery products established by the European Legislation. Taking into account the role of biotic and abiotic factors in the accumulation of these pollutants in fish (Verhaert et al., 2017 and Storelli et al., 2002), the dependences between pollutant concentrations, fish species and specimen weight have been also evaluated.

The results of the present study need to be considered to design guidelines for decreasing human incorporation of these compounds through diet which is consistent with the EFSA (2015) recommendations.

\section{Materials and methods}

\subsection{Sampling}

Between March 2016 and August 2017, 104 commercial fish samples from the Western Mediterranean Sea were collected (Fig. 1). Most of them $(n=102)$ in waters nearby the Balearic Islands (Majorca, $n=66$; Menorca, $n=17$; Ibiza, $n=18$ ) and the rest of the samples were from Tunisia $(n=2)$ and Egypt $(n=1)$. Additional fish samples $(n=14)$ from the Atlantic Ocean, in front of the Senegal $(n=4)$ and Mauritania $(n=10)$ coasts, were also collected.

Twenty-one lean fish species from the Balearic Islands were selected considering those most consumed by the population (Table 1; SMAP, 2015). They encompassed angler (Lophius piscatorius), European hake (Merluccius merluccius), common dentex (Dentex dentex), common pandora (Pagellus erythrinus), dusky grouper (Epinephelus marginatus), Mediterranean moray (Muraena helena), red scorpionfish (Scorpaena scrofa), small-spotted catshark (Scyliorhinus canicula), conger (Conger conger), Mediterranean rainbow grasse (Coris julis), four-spot megrim (Lepidorhombus boscii), annular seabream (Diplodus annularis), common two-banded seabream (Diplodus vulgaris), John dory (Zeus faber), 


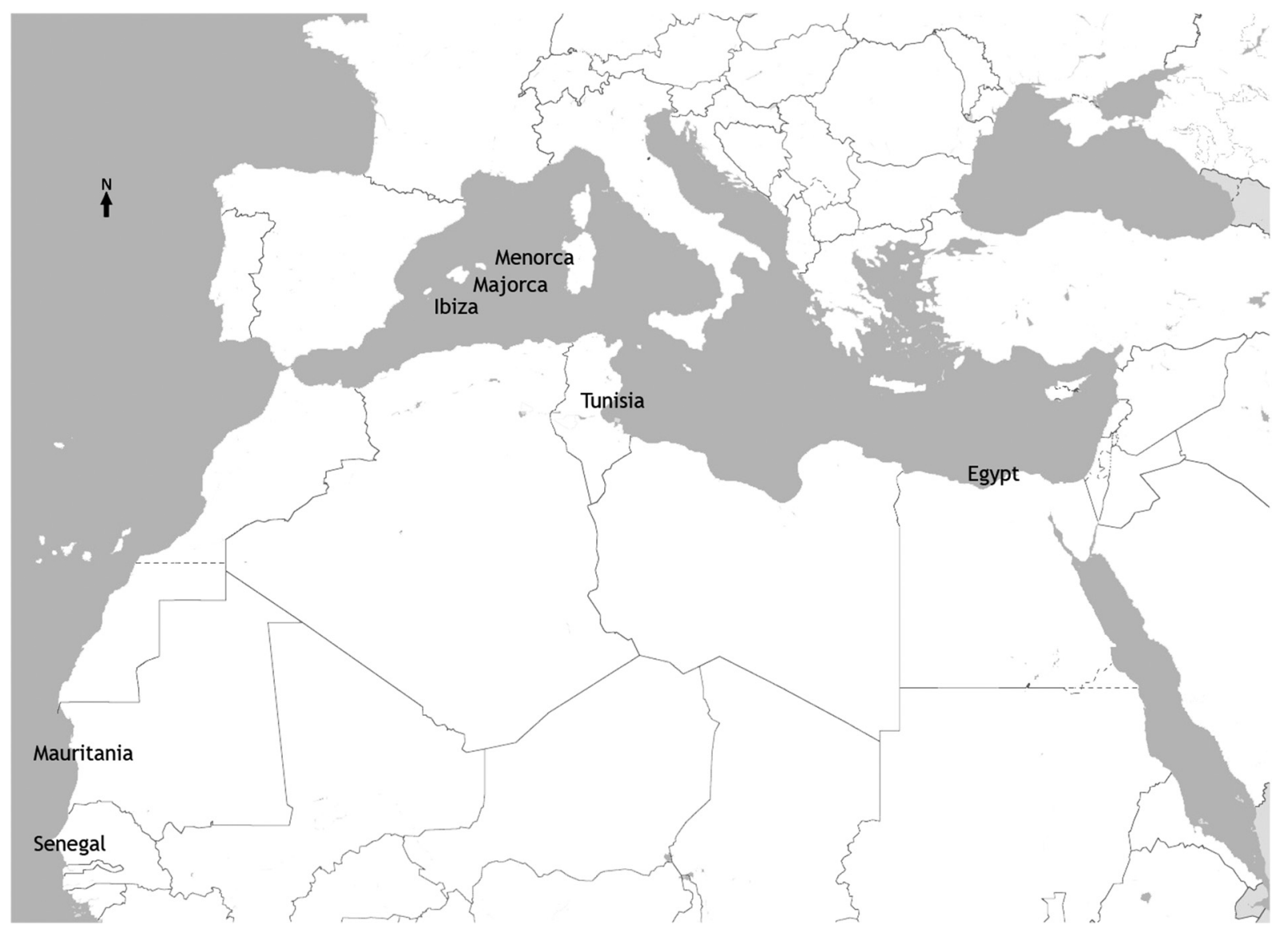

Fig. 1. Map of the areas in which fish were collected.

common dolphinfish (Coryphaena hippurus), pearly razorfish (Xyrichtys novacula), white seabream (Diplodus sargus), comber (Serranus cabrilla), greater amberjack (Seriola dumerili), Atlantic horse mackerel (Trachurus trachurus) and painted comber (Serranus scriba). These species were obtained by both commercial and recreational fishing. Samples were collected in action halls and local fish markets. Those from

Table 1

Lean fish analysed in this study.

\begin{tabular}{lll}
\hline Common name & Scientific name & Habitat \\
\hline Second trophic level & & \\
Mediterranean rainbow wrasse & Coris julis & Benthic \\
Four-spot megrim & Lepidorhombus boscii & Benthic \\
Annular seabream & Diplodus annularis & Benthic \\
Common two-banded seabream & Diplodus vulgaris & Benthic \\
Small-spotted catshark & Scyliorhinus canicula & Benthic \\
Common pandora & Pagellus erythrinus & Benthic \\
Pearly razorfish & Xyrichtys novacula & Benthic \\
White seabream & Diplodus sargus & Benthic \\
Comber & Serranus cabrilla & Benthic \\
Atlantic horse mackerel & Trachurus trachurus & Pelagic \\
Painted comber & Serranus scriba & Benthic \\
& & \\
Third trophic level & & Benthic \\
Angler & Lophius piscatorius & Benthic \\
Dusky grouper & Epinephelus marginatus & Benthic \\
Conger & Conger conger & Benthopelagic \\
Common dentex & Dentex dentex & Benthic \\
Mediterranean moray & Muraena helena & Benthic \\
European hake & Merluccis merluccis & Benthic \\
Red scorpionfish & Scorpaena scrofa & Benthic \\
John Dory & Zeus faber & Pelagic \\
Common dolphinfish & Coryphaena hippurus & Pelagic \\
Greater amberjack & Seriola dumerili & \\
\hline
\end{tabular}

Tunisia, Egypt and the Atlantic Ocean (belonging only to the dusky grouper species), were obtained from importer facilities in the Balearic Islands. Information on length, weight, date of sampling and catch location was obtained.

The studied fish species were grouped into two trophic levels: (i) those feeding on small fish and crustaceans (trophic level 2 , encompassing 31 specimens from eleven species); and (ii) piscivorous species that feed on fish and cephalopods (trophic level 3, encompassing 87 specimens from ten species) (Riera et al., 1995).

\subsection{Chemicals and analytes of interest}

The following pollutants were considered for analysis: pentachlorobenzene (PeCB), hexachlorobenzene (HCB), 4 isomers of hexachlorocyclohexanes $(\alpha-, \beta-, \gamma$ - and $\delta$-HCH), 2,4'-DDT, 4,4'-DDT and three metabolites (2,4'-DDE, 4,4'-DDE and 4,4'-DDD), 6 PCB congeners (28, $52,118,138,153$ and 180 ) and total $\mathrm{Hg}$.

Solvents for residue analysis, $n$-hexane, dichloromethane, isooctane, acetone, concentrated 95-97\% sulfuric acid, sodium sulfate and silica gel were from Merck (Darmstadt, Germany). Sulfate and silica were activated overnight by heating at $400{ }^{\circ} \mathrm{C}$ and $120^{\circ} \mathrm{C}$, respectively. The cellulose extraction cartridges $(22 \mathrm{~mm} \times 80 \mathrm{~mm}$ ) were from Whatman International Ltd. (UK). The standards of PeCB, HCB, HCHs, DDTs and PCB congeners were from Dr. Ehrenstorfer (Wesel, Germany). 1,2,4,5Tetrabromobenzene (TBB) was from (Aldrich Steinheim, Germany). The standard mixtures of organochlorine compounds, surrogate solution composed of TBB and PCB 209, and internal standard of PCB 142, were prepared in isooctane. Fish muscle certified reference material, ERM-BB422, was obtained from the Institute for Reference Materials and Measurements (Geel, Belgium). 


\subsection{Determination of organochlorine compounds}

The extraction and clean-up of organochlorine compounds in fish samples was based on previous analytical procedures (Berdie and Grimalt, 1998, Vives and Grimalt, 2002).

Briefly, each muscle sample (3-4 g) was homogenized with activated sodium sulfate until a fine powder was obtained and then the mixtures were introduced into previously cleaned cellulose cartridges ( $6 \mathrm{~h}$ in Soxhlet). These mixtures were Soxhlet-extracted with $100 \mathrm{~mL}$ of $n$-hexane-dichloromethane $(4: 1 \mathrm{v} / \mathrm{v})$ for $6 \mathrm{~h}$. At this step, TBB and PCB 209 were added as recovery standards ( $50 \mathrm{ng} / \mathrm{mL}$ ). The extract was concentrated with a rotary evaporator to $2 \mathrm{~mL}$ and then $3 \mathrm{~mL}$ of sulfuric acid were added. After vigorous stirring in a Vortex-mixer (2 min) the mixture was centrifuged ( $4000 \mathrm{rpm}, 5 \mathrm{~min}$ ) to remove any foam in the interface and the sulfuric acid layer was discarded. This clean-up step was repeated until a colorless transparent acid layer was obtained (3-5 times). The solvent layer was introduced into a chromatographic column packed with $1 \mathrm{~g}$ of sodium sulfate and silica gel column (1:1 by weight). The extract was then evaporated to dryness under a gentle stream of nitrogen $\left(10-20^{\circ} \mathrm{C}\right)$ and transferred to vials using $200 \mu \mathrm{L}$ of isooctane. Before instrumental analysis, the sample was evaporated to nearly dryness under a gentle nitrogen flow and a solution of PCB 142 was added as internal standard $(10 \mathrm{ng} / \mathrm{mL})$.

OCs were quantified using a gas chromatograph with electron capture detection (GC-ECD, Agilent Technologies 7890A, Palo Alto, California, USA) equipped with a HP-5MS capillary column of $60 \mathrm{~m}$ length, $0.25 \mathrm{~mm}$ internal diameter and $0.25 \mu \mathrm{m}$ film thickness (J\&W Scientific, Folsom, CA, USA), protected with a retention gap. The oven temperature was programmed from $90{ }^{\circ} \mathrm{C}$ (holding time $2 \mathrm{~min}$ ) to $130{ }^{\circ} \mathrm{C}$ at $15^{\circ} \mathrm{C} /$ min and finally to $290{ }^{\circ} \mathrm{C}$ at $4{ }^{\circ} \mathrm{C} / \mathrm{min}$, keeping the final temperature for $15 \mathrm{~min}$. Injector and detector temperatures were $250{ }^{\circ} \mathrm{C}$ and 320 ${ }^{\circ} \mathrm{C}$, respectively. Injection $(2 \mu \mathrm{L})$ was performed in splitless mode, keeping the split valve closed for $30 \mathrm{~s}$. Helium was the carrier gas $(1.5 \mathrm{~mL} / \mathrm{min})$ and nitrogen was used as the make-up gas for the detector (60 mL/min).

Structural confirmations were performed by gas chromatography (GC, Agilent Technologies 7890A, Agilent Palo Alto, USA) coupled to a mass spectrometer (MS, Agilent Technologies 5975C, Agilent Palo Alto, USA) operating in negative chemical ionization mode (GC-NICI-MS). The system was equipped with a HP-5MS capillary column of $60 \mathrm{~m}$ length, $0.25 \mathrm{~mm}$ internal diameter and $0.25 \mu \mathrm{m}$ film thickness (J\&W Scientific, Folsom, CA, USA), protected with a retention gap. Helium was used as carrier gas $(1.2 \mathrm{~mL} / \mathrm{min})$. Ammonia was the reagent gas $(2.5 \mathrm{~mL} / \mathrm{min})$. The oven temperature program started at $90{ }^{\circ} \mathrm{C}$ which was held for $2 \mathrm{~min}$, followed by a first increase to $130{ }^{\circ} \mathrm{C}$ at $15^{\circ} \mathrm{C} / \mathrm{min}$ and a final ramp to $310^{\circ} \mathrm{C}$ at $4{ }^{\circ} \mathrm{C} / \mathrm{min}$ with a hold time of $10 \mathrm{~min}$. Injector, transfer line and ion source temperatures were $280{ }^{\circ} \mathrm{C}, 280{ }^{\circ} \mathrm{C}$ and $176{ }^{\circ} \mathrm{C}$, respectively. The dwell time was $50 \mathrm{~ms} /$ channel.

One procedural blank was included in each batch of samples. Mean recoveries of spiked standards in the samples were $56 \%$ and $77 \%$ for TBB and PCB 209, respectively. Detection and quantification limits were determined as the average signal obtained from the blanks plus three and five times the standard deviation, respectively. Detection limits ranged between 0.0050 and $0.095 \mathrm{ng} / \mathrm{g}$ wet weight (ww) and quantification limits, between 0.038 and $0.14 \mathrm{ng} / \mathrm{g}$ ww.

\subsection{Determination of mercury}

Total Hg was performed using inductively coupled plasma mass spectrometry (ICP-MS, Agilent Technologies 7900, Agilent Palo Alto, USA) operating under standard conditions and using iridium as internal standard. Helium was used as a carrier gas ( $5 \mathrm{~mL} / \mathrm{min})$. One procedural blank was included in each sample batch. The limits of quantification (LQs) were $0.1 \mathrm{mg} / \mathrm{kg}$ ww. These analyses were performed at the Public Health Laboratory of Palma (Mallorca; ENAC accreditation 603/LE1307).

\subsection{Estimated dietary intakes and threshold values}

All fish species considered in the study are usually consumed by the Spanish population (BOE, 2015). In addition, 5 of the species analysed (Conger conger, Lepidorhombus boscii, Lophius piscatorius, Merluccis merluccis and Trachurus trachurus) are in the 30 main fishing species of commercial interest according to the Spanish Ministry of Agriculture and Fisheries (Government of Spain, 2012).

A first estimation of the dietary weekly total $\mathrm{Hg}$ intakes ( $\mathrm{mg} \mathrm{Hg}$ ) through fish consumption was calculated by multiplying the median fish concentrations of all analysed samples ( $\mathrm{mg} / \mathrm{kg} \mathrm{ww}$ ) by the weekly average fish consumptions of the Spanish population (AESA, 2006). Following the recommendations of EFSA 50th and 95th percentiles of consumption have been used to assess the middle bound $(\mathrm{MB})$ and upper bound (UB) for both children (7-12 years old; $\mathrm{MB}=46.4 \mathrm{~g} /$ day and $\mathrm{UB}=383 \mathrm{~g} /$ day) and adults (older than 17 years: $\mathrm{MB}=71.1 \mathrm{~g} /$ day and $\mathrm{UB}=597 \mathrm{~g} /$ day), respectively (EFSA, 2015). Comparison of these results with those reported by EFSA for Spain gave similar figures, e.g. $36.3 \mathrm{~g} /$ day and $63.6 \mathrm{~g} /$ day for children and adults, respectively (EFSA, 2015). Estimated Weekly Intakes (EWIs; $\mu \mathrm{g} / \mathrm{kg}$ bw) of total Hg were obtained from the dietary weekly intakes after normalization to the mean body weights of each population group, e.g. $34.48 \mathrm{~kg}$ for children and $68.48 \mathrm{~kg}$ for adults.

The EWIs were compared to the PTWIs of both THg and MeHg, 4 $\mu \mathrm{g} / \mathrm{kg}$ bw and $1.3 \mu \mathrm{g} / \mathrm{kg}$ bw, respectively (EFSA, 2012). The PTWI percentages (\%PTWI) were calculated as $100 \cdot$ EWI/PTWI.

\subsection{Statistical analysis}

The statistical analyses were performed using R ( $\mathrm{R}$ Core Team, 2015) software and Microsoft Excel (2010). The concentrations of OCs and $\mathrm{Hg}$ were expressed in ng/g ww and $\mathrm{mg} / \mathrm{kg} \mathrm{ww}$, respectively. When OCs and $\mathrm{Hg}$ concentrations were under the limit of detection or quantification, the values were assumed to be one-half of the detection or quantification limits, respectively ( $\mathrm{ND}=1 / 2 \mathrm{LOD} ; 1 / 2 \mathrm{LOQ}$, respectively). For THg, concentrations below LQs were assumed to be $1 / 2$ of the LQs, $0.05 \mathrm{mg} / \mathrm{kg}$ ww. Similar figures were obtained from the calculation of these values with a reverse Kaplan-Meier estimator (Gillespie et al., 2010). Either ww or dry weight (dw) were used for comparison with other studies.

Total HCHs were defined as the sum of $\alpha-, \beta-, \delta$ - and $\gamma$-HCHs. Total DDT concentrations were the sum of $4,4^{\prime}$-DDT, 2,4'-DDT, 4, $4^{\prime}$-DDE, $2,4^{\prime}$-DDE and 4,4'-DDD. Total PCB concentrations were the sum of 28 , $52,118,138,153$ and 180 . HCB and Hg were reported as individual compounds. Concentration means and ranges were used for data reporting. The concentrations were not normally distributed and graphics were displayed in a logarithmic scale (Figs. 2 and 4-6). Non-parametric Kruskal-Wallis test was used for assessing the differences on pollutant concentrations by location and trophic level. Pearson correlation test of log-transformed values and Spearman correlation test of nontransformed values, as well as simple linear regression models were applied for evaluation of the relationships between pollutant concentration and fish weights.

\section{Results and discussion}

The present study reports the concentrations of organochlorine pollutants and $\mathrm{Hg}$ in 118 fish specimens from 21 species (Table 1 ) collected at several locations of the Western Mediterranean Sea and the Atlantic coast (Fig. 1). Dusky grouper, Mediterranean moray and common dentex were the most studied species, with a total of 15 to 28 specimens for each species examined.

The distributions of the concentrations of HCB, total DDTs, PCBs and $\mathrm{Hg}$ of the studied species displayed in Table 1 are shown in Fig. 2. Hg and total DDTs show highest variability between species whereas PCBs and HCB display more constant median values between species (Fig. 2). 

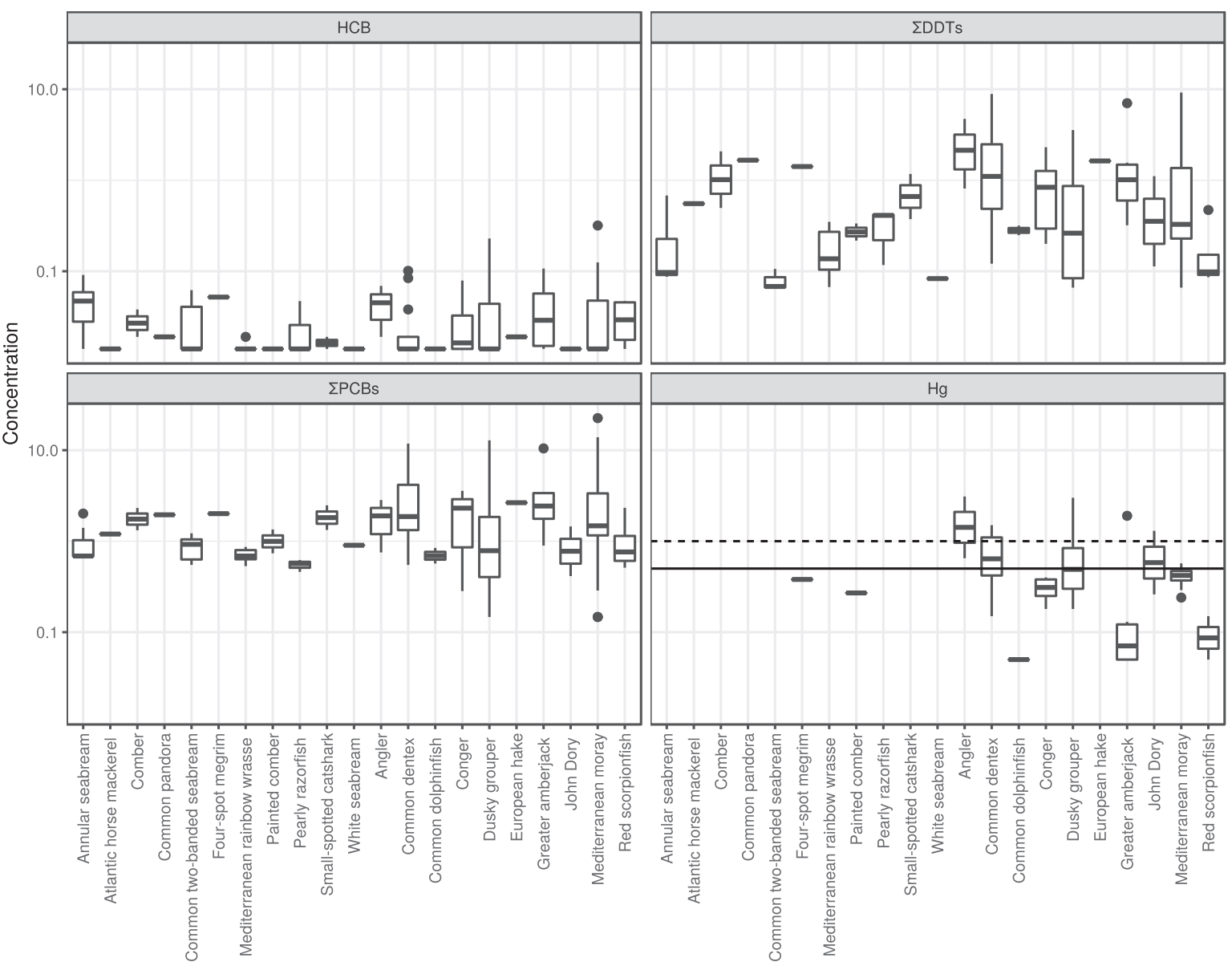

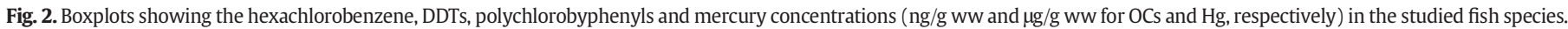
The EU mercury threshold levels of 0.5 and $1 \mu \mathrm{g} / \mathrm{g}$ ww for human consumption $(E C, 2006)$ are indicated.

Angler is the specie showing the highest median concentration of $\mathrm{Hg}$ $(1.9 \mu \mathrm{g} / \mathrm{g})$ and DDTs $(3.4 \mathrm{ng} / \mathrm{g})$.

\subsection{Occurrence of organochlorine compounds}

The concentrations of organochlorine compounds in the fish specimens range between not detected and $32 \mathrm{ng} / \mathrm{g}$ ww (Table 2, Fig. 2). Those concentrations are lower than the European Union threshold recommended for human consumption, $75 \mathrm{ng} / \mathrm{g}$ ww (DOUE, 2011). The PCB congeners found in highest concentrations in all samples were those with highest molecular weights, PCB118, РCB138, PCB153 and PCB180, which involves those with highest hydrophobic properties (octanol-water coefficients, $\operatorname{logKow}>6.9$ ). The predominance of these compounds is consistent with their high hydrophobicity and bioaccumulation potential. Concerning DDTs, the species average $100 * 4,4^{\prime}-$ DDT $/\left(4,4^{\prime}\right.$-DDT $+4,4^{\prime}$-DDE) ratios are between 3.5 and 33\%, indicating that the observed DDT concentrations correspond to old spills in the Mediterranean waters.

The mean concentration of HCB in the Atlantic fish, $0.04 \mathrm{ng} / \mathrm{g} \mathrm{ww}$ was slightly higher than in the Mediterranean fish, $0.03 \mathrm{ng} / \mathrm{g} \mathrm{ww}$, but the differences were not significant (Table 2, Fig. 3). For the rest of organochlorine compounds, the concentrations were higher in fish from the Mediterranean Sea than in those from the Atlantic Ocean, especially for DDTs and PCBs (Table 2). The differences were not significant for total HCHs but for total DDTs and PCBs these differences were significant ( $p<0.01$, data not shown).

In any case, the observed concentrations in the specimens captured nearby the Balearic Islands were lower than in the fish specimens consumed in Sweden, Catalonia, Austria and Russia (Table 2). The differences were particularly significant for the DDT and the PCB groups since the average concentrations found in the fish from the Balearic Islands were about 6-7 times lower than the average concentrations reported in Catalonia (Martí-Cid et al., 2010; Llobet et al., 2003) or Russia (Polder et al., 2010) (Table 2). The concentrations of total HCHs, DDTs and PCBs were also lower than those described in Croatia (KljakovicGaspic et al., 2015). With the exception of HCB the concentrations of the organochlorine compounds from fish captured near the Canary Islands were lower than those in the Balearic Islands analysed in the present study (Table 2). The average concentrations of HCB, total HCHs and total DDTs in fish captured nearby the Balearic Islands are quite similar than those observed in fish captured near Menorca (Junqué et al., 2017). However, the PCB concentrations are higher in the present case, $2.4 \mathrm{ng} / \mathrm{g}$ ww vs. $1.7 \mathrm{ng} / \mathrm{g} \mathrm{ww}$ (Table 2 ). In general, decreasing concentrations in OCs have been observed (Krauthacker et al., 2009; Aguilar and Borrell, 2005), probably as the result from the application of the Stockholm Convention.

\subsection{Mercury}

The concentration of total $\mathrm{Hg}$ in the studied fish specimens ranges between not detected and $3 \mu \mathrm{g} / \mathrm{g}$ ww. For certain species (e.g. common dentex, John dory), the median concentrations were well above the EU threshold of $0.5 \mu \mathrm{g} / \mathrm{g}$ ww (EC, 2006). This previous range does not include angler, whose specimens have values of $0.65-3.1 \mu \mathrm{g} / \mathrm{g}$ ww which also have an upper limit that is above the EU threshold for this species, $1 \mu \mathrm{g} / \mathrm{g}$ ww. Thirty-nine percent of the specimens from the Mediterranean, excluding angler, have $\mathrm{Hg}$ concentrations above the $\mathrm{EU}$ threshold of $0.5 \mu \mathrm{g} / \mathrm{g}$ ww whereas $25 \%$ of the Dusky grouper specie 
Table 2

Arithmetic mean concentrations of OCs in food items of Menorca and in other European sites (ng/g ww).

\begin{tabular}{|c|c|c|c|}
\hline & Fish & Location & Reference \\
\hline HCB & & & Present study \\
\hline Mediterranean & 0.03 & & \\
\hline \multirow[t]{8}{*}{ Atlantic } & 0.04 & & \\
\hline & 0.33 & Canary Islands & Rodríguez-Hernández et al., 2016 \\
\hline & 0.021 & Croatia & Kljakovic-Gaspic et al., 2015 \\
\hline & 0.45 & Sweden & A. Törnkvist et al., 2011 \\
\hline & 0.22 & Catalonia & Martí-Cid et al., 2010 \\
\hline & 0.28 & Catalonia & Falcó et al., 2004 \\
\hline & 0.053 & Menorca & Junqué et al., 2017 \\
\hline & 0.56 & Russia & Polder et al., 2010 \\
\hline$\sum \mathrm{HCHs}$ & & & Present study \\
\hline Mediterranean & 0.05 & & \\
\hline \multirow[t]{8}{*}{ Atlantic } & 0.039 & & \\
\hline & 0.13 & Canary Islands & Rodríguez-Hernández et al., 2016 \\
\hline & 0.32 & Croatia & Kljakovic-Gaspic et al., 2015 \\
\hline & 0.23 & Sweden & Törnkvist et al., 2011 \\
\hline & 0.20 & Catalonia & Martí-Cid et al., 2010 \\
\hline & 0.038 & Menorca & Junqué et al., 2017 \\
\hline & 0.28 & Russia & Polder et al., 2010 \\
\hline & 0.12 & Xiamen (China) & Qian et al., 2017 \\
\hline$\sum \mathrm{DDTs}$ & & & Present study \\
\hline Mediterranean & 1.1 & & \\
\hline \multirow[t]{8}{*}{ Atlantic } & 0.17 & & \\
\hline & 0.77 & Canary Islands & Rodríguez-Hernández et al., 2016 \\
\hline & 2.8 & Croatia & Kljakovic-Gaspic et al., 2015 \\
\hline & 3.3 & Sweden & Törnkvist et al., 2011 \\
\hline & 7.5 & Catalonia & Martí-Cid et al., 2010 \\
\hline & 1.1 & Menorca & Junqué et al., 2017 \\
\hline & 6.4 & Russia & Polder et al., 2010 \\
\hline & 6.1 & Xiamen (China) & Qian et al., 2017 \\
\hline$\sum \mathrm{PCBs}$ & & & Present study \\
\hline Mediterranean & 2.4 & & \\
\hline \multirow[t]{10}{*}{ Atlantic } & 0.67 & & \\
\hline & 1.3 & Canary Islands & Rodríguez-Hernández et al., 2016 \\
\hline & 4.3 & Austria & Mihats et al., 2015 \\
\hline & 11 & Croatia & Kljakovic-Gaspic et al., 2015 \\
\hline & 5.1 & Sweden & Törnkvist et al., 2011 \\
\hline & 11 & Catalonia & Martí-Cid et al., 2010 \\
\hline & 12 & Catalonia & Llobet et al., 2003 \\
\hline & 1.7 & Menorca & Junqué et al., 2017 \\
\hline & 7.4 & Russia & Polder et al., 2010 \\
\hline & 4.1 & Xiamen (China) & Qian et al., 2017 \\
\hline
\end{tabular}

from the Atlantic Ocean analysed in the present study show values above this limit.

The Hg concentrations observed in the present study were consistent with previous results reported in the same organisms from the Adriatic Sea (Storelli and Barone, 2013; Storelli et al., 2007), Farwa Island (Lybian coast; Banana et al., 2016), the Gulf of Lion (Torres et al., 2015; Cresson et al., 2014), the Aegean Sea (Yabanli and Alparslan, 2015), Menorca (Junqué et al., 2017) and deep-sea sites from the Mediterranean basin (Koenig et al., 2013; Naccari et al., 2015).

The mean $\mathrm{THg}$ concentrations of the angler specimens analysed in the present study ( $1.9 \mu \mathrm{g} / \mathrm{g} \mathrm{ww})$ were much higher than those from the Italian coast (mean of $0.13 \mu \mathrm{g} / \mathrm{g}$ ww; Brambilla et al., 2013) and even previous studies near the Balearic Islands $(0.74 \mu \mathrm{g} / \mathrm{g}$ ww; Llull et al., 2017).

The concentrations of mercury in dusky groupers from the Balearic Islands, $1.5 \mu \mathrm{g} / \mathrm{g}$ ww ww $(n=8)$, are similar to those found in a previous study of the same area, $1.6 \mu \mathrm{g} / \mathrm{g}$ ww, and higher than those observed in Tunisia, $0.86 \mathrm{mg} / \mathrm{kg} \mathrm{ww}$, and Egypt, $0.92 \mu \mathrm{g} / \mathrm{g} \mathrm{ww}$, or in the Atlantic Ocean (mean $0.34 \mu \mathrm{g} / \mathrm{g}$ ww; $n=14$ ). In the present study, fish from the Atlantic Ocean had $\mathrm{Hg}$ levels of $0.43 \mu \mathrm{g} / \mathrm{g}$ ww $(n=14)$.

Common dentex were found to have mean Total $\mathrm{Hg}$ concentrations of $0.78 \mu \mathrm{g} / \mathrm{g}$ ww which was lower than in a previous study in the western Mediterranean, $0.99 \mu \mathrm{g} / \mathrm{g} w \mathrm{w}$, and in the Egyptian coast, $1.1 \mu \mathrm{g} / \mathrm{g}$ ww (Llull et al., 2017).

\subsection{Pollution differences between Mediterranean and Atlantic concentrations}

Comparison of the differences in pollutant concentrations in dusky groupers between the specimens analysed in the Mediterranean Sea $(n=14)$ and the Atlantic Ocean $(n=14)$ shows important contrasts (Fig. 3). The mean differences of THg, total DDTs and PCBs between dusky grouper specimens from Mediterranean Sea and Atlantic Ocean are statistically significant ( $1.5 \mathrm{vs} .0 .43 \mu \mathrm{g} / \mathrm{g}$ ww, $1.3 \mathrm{vs.} 0.16 \mathrm{ng} / \mathrm{g}$ ww and 3.2 vs. $0.57 \mathrm{ng} / \mathrm{g}$ ww, respectively, with Kruskal-Wallis test's, $p$ values $<0.001$; Fig. 3 ). In contrast, no significant differences are found for HCB ( 0.03 vs. $0.05 \mathrm{ng} / \mathrm{g}$ ww, $p$-value 0.084 ). This contrast reflects the higher pollution inputs in the Mediterranean. However, the difference is more defined for the organic compounds with higher capacity of fish bioaccumulation, such as those with $\operatorname{logKow}>6.9$, compounds with lower bioaccumulation capacity are not retained in the food web
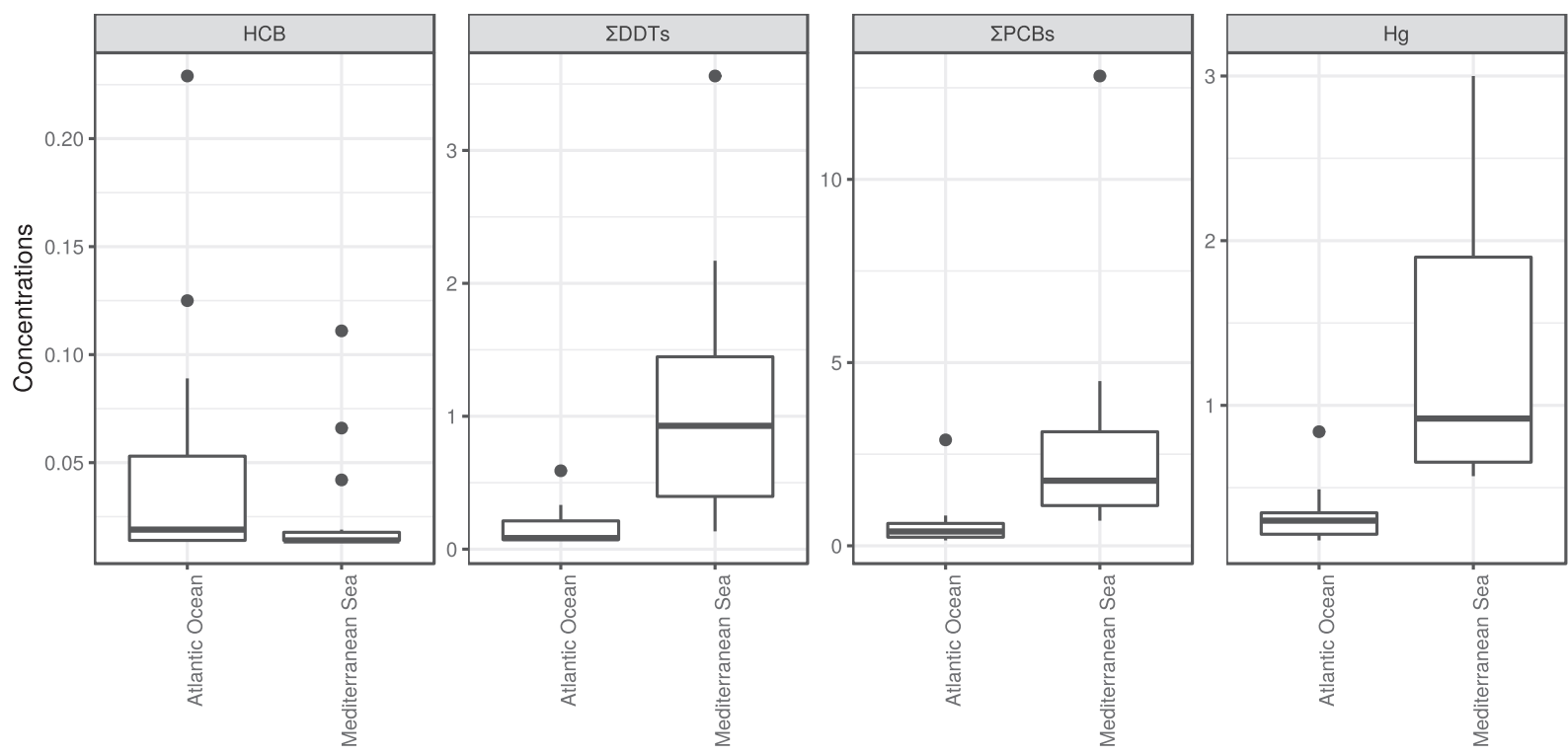

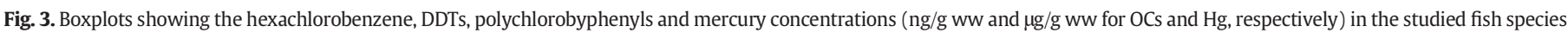
in the Mediterranean Sea and the Atlantic Ocean. 
and therefore no difference in accumulation of these compounds between Mediterranean and Atlantic fish specimens is observed.

\subsection{Trophic level}

The concentration differences between the second and third trophic levels are summarized in Fig. 4. No median difference in the concentration of HCB is observed between the two levels. For Hg, total DDTs and PCBs, higher median concentrations in the third level are found. The differences are only significant for total DDTs and PCBs (data not shown). Again, considering the physical-chemical properties of the organochlorine compounds the contrast between these two pollutant groups and HCB is related to the capacity for bioaccumulation of the former and therefore higher pollution inputs are retained in the species from higher trophic level which retain the pollutants ingested from lower food web species.

$\mathrm{MeHg}$ has been reported to generally increase at higher size and age which recommends to consider specimen length, weight and age for concentration data interpretation (Wiener et al., 2007). Representation of the median $\mathrm{Hg}$ concentrations of each Table 1 third trophic level species by median weight shows an increasing trend and the correlation is significant $r=0.81(p<0.001$; Fig. 5$)$. The species having larger-size individuals, higher weight, are those accumulating $\mathrm{Hg}$ at higher extent. Representation of the $\mathrm{Hg}$ concentrations vs. weight of each specimen shows again a significant correlation with nearly the same correlation coefficient and degree of significance, $r=0.78$ ( $p<0.01$; Fig. 5 ). It is therefore difficult to discriminate between species or individual weight/size in the accumulation of $\mathrm{Hg}$. Plotting the $\mathrm{Hg}$ concentrations vs individual weight for each species shows higher concentrations at higher weight in each species except in Mediterranean moray (Fig. 6).
Accordingly, the weight/size effect of the individuals is an important factor determining $\mathrm{Hg}$ accumulation. Nevertheless, important differences between concentration increases vs weight are observed depending on each species (Fig. 6), evidencing that there is also a species effect in the accumulation of this metal. No significant dependences between longitude of the individuals and concentrations of the organochlorine compounds are observed.

\subsection{Dietary exposure assessment}

According to the results of the present study, the average THg intake due to fish consumption of all collected species in the present study, $0.61 \mu \mathrm{g} / \mathrm{g} \mathrm{ww}$, involves $\mathrm{Hg}$ EWIs of $5.7 \mu \mathrm{g} / \mathrm{kg}$ bw for children aged 7-12 years and $4.4 \mu \mathrm{g} / \mathrm{kg}$ bw for adults when referred to the infant and general Spanish population (AESA, 2006). These values are higher than the PTWI for total $\mathrm{Hg}$ intake recommended by FAO/WHO, 4 $\mu \mathrm{g} / \mathrm{kg}$ bw (EFSA, 2012), $140 \%$ and $110 \%$, respectively. In the worst case scenario (UB approach), the children and adults would be exposed to $47.25 \mu \mathrm{g} / \mathrm{kg}$ bw and $37.08 \mu \mathrm{g} / \mathrm{kg}$ bw, which exceed largely the established upper limit, $1181 \%$ and $927 \%$, respectively. For MeHg, assuming that $90 \%$ of total $\mathrm{Hg}$ is in this form, the EWIs are $5.2 \mu \mathrm{g} / \mathrm{kg}$ bw and $4.0 \mu \mathrm{g} / \mathrm{kg}$ bw for MB and $42.5 \mu \mathrm{g} / \mathrm{kg}$ bw and $33.4 \mu \mathrm{g} / \mathrm{kg}$ bw for UB in children and adults, respectively. The PTWI for MeHg are set to 1.3 $\mu \mathrm{g} / \mathrm{kg}$ bw (EFSA, 2012) which is lower than the EWIs for children and adults. According to these PTWIs, the observed EWIs for children and adults are $400 \%$ and $310 \%$ of the PTWIs for MB and $3269 \%$ and $2596 \%$ for $U B$ respectively.

These values represent the worst case scenarios in which only local fish is consumed. Fish from other Mediterranean areas and the Atlantic
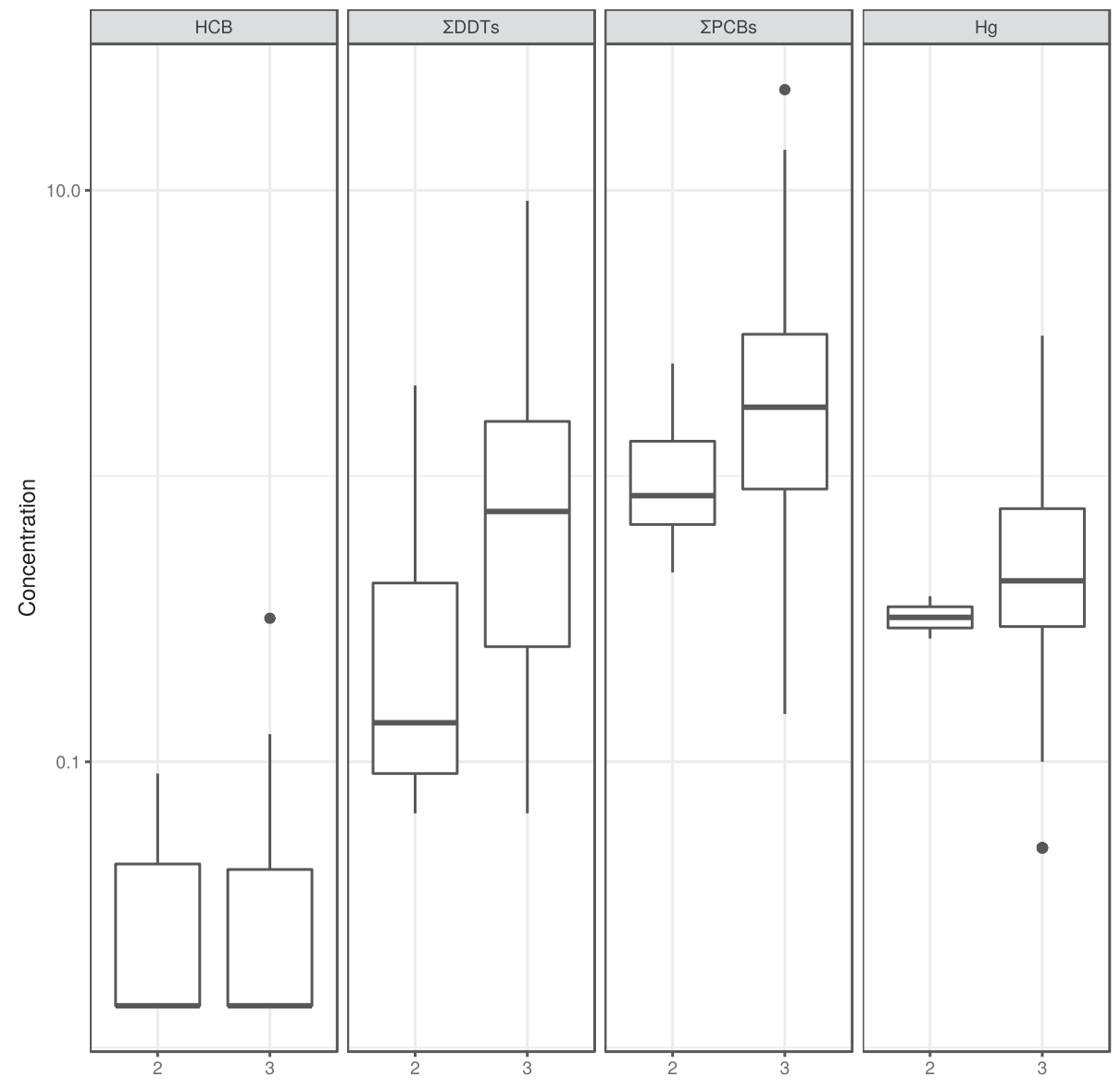

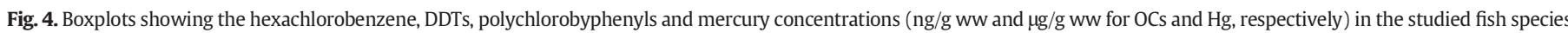
belonging to the second trophic level (feeding on small fish and crustaceans) or to the third trophic level (feeding on fish and cephalopods). 

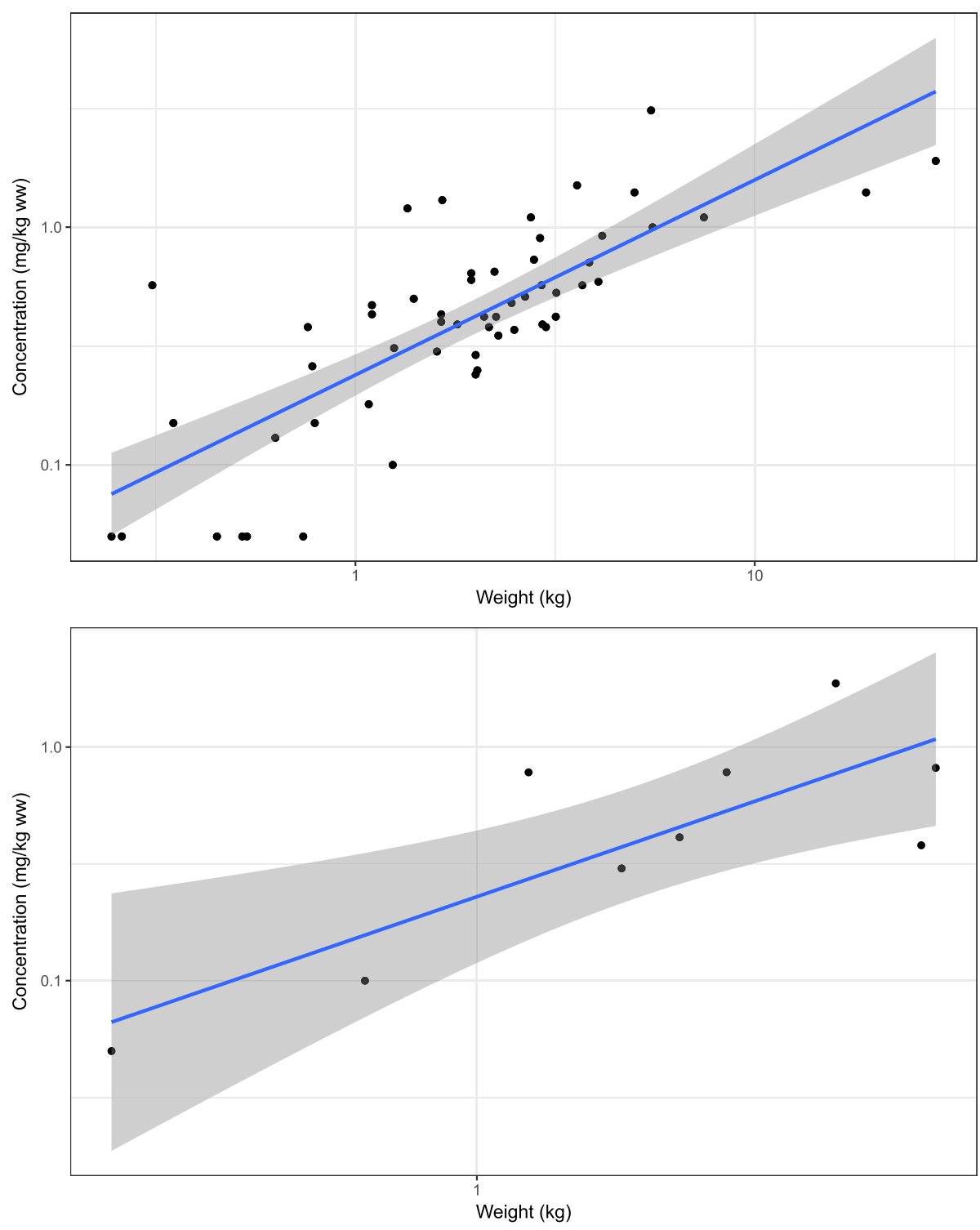

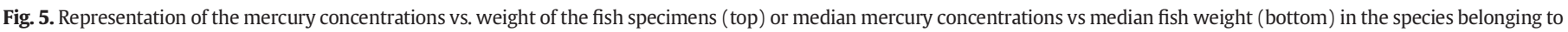
the third trophic level (see Fig. 4). The coloured area around the curve fitted line correspond to the 95\% confidence interval.

Ocean is also commercialized in the Balearic Islands. Consumption from local sites is less than half of the total.

This evaluation of mercury ingestion by fish consumption may be compared with those of other Mediterranean populations. Two studies performed in Italy on target fish species found higher EWIs than in the present study (Storelli and Barone, 2013; Bonsignore et al., 2013). Studies in Valencia showed that total fish consumption contributed to $43 \%$ of PTWI (Yusa et al., 2008) whereas these contributions in Catalonia were $49.3 \%$ for adults and 38.5\% for children (Llobet et al., 2003; Falcó et al., 2006).

In the case of $\mathrm{HCB}$, total $\mathrm{HCHs}$, DDTs and PCBs, the average concentrations, $0.027 \mathrm{ng} / \mathrm{g} w \mathrm{w}, 0.047 \mathrm{ng} / \mathrm{g}$ ww, $0.93 \mathrm{ng} / \mathrm{g}$ ww and $1.7 \mathrm{ng} / \mathrm{g}$ ww, respectively, correspond to $0.03 \mathrm{ng} / \mathrm{kg}$ bw d, $0.05 \mathrm{ng} / \mathrm{kg}$ bw d, $0.96 \mathrm{ng} / \mathrm{kg}$ bw d and $1.8 \mathrm{ng} / \mathrm{kg}$ bw d, respectively, for adults and $0.03 \mathrm{ng} / \mathrm{kg}$ bw d, $0.06 \mathrm{ng} / \mathrm{kg}$ bw d, $1.1 \mathrm{ng} / \mathrm{kg}$ bw d and $2.1 \mathrm{ng} / \mathrm{kg}$ bw d, respectively, for children in the MB approach. The same estimations for HCB, total HCHs, DDTs and PCBs in high consumers, correspond to and $0.3,0.52,10.3,19,27$ for children and 0.24, 0.41, 8.08 and $15.12 \mathrm{ng} / \mathrm{kg}$ bw $\mathrm{d}$ for adults.

The EWI in MB and UB in children and adults are much lower than the PTWIs recommended by the Joint FAO/WHO Meeting on Pesticide
Residues, 160, 5000, 10,000 and $10 \mathrm{ng} / \mathrm{kg}$ bw d, respectively (JMPR, 2000).

\section{Conclusions}

$\mathrm{Hg}$ and total DDTs showed highest variability between species whereas PCBs and HCB displayed more constant median values between species. The PCB congeners found in highest concentrations in all lean fish samples were those with highest molecular weight, PCB118, PCB138, PCB153 and PCB180, e.g. those with highest hydrophobicity (logKow $>6.9$ ). The predominance of these compounds was consistent with the high bioaccumulation potential. The DDT distributions were predominated by 4,4'-DDE which corresponded to old spills of these compounds.

The concentrations of organochlorine compounds were higher in fish from the Mediterranean Sea than from the Atlantic Ocean but the average differences were only significant for the compounds with high bioaccumulation potential, e.g. total DDTs and PCBs. Fish from the third trophic level showed higher median concentrations of DDTs and PCBs than those from the second trophic level, with statistically significant results. Again the differences were only significant for the 


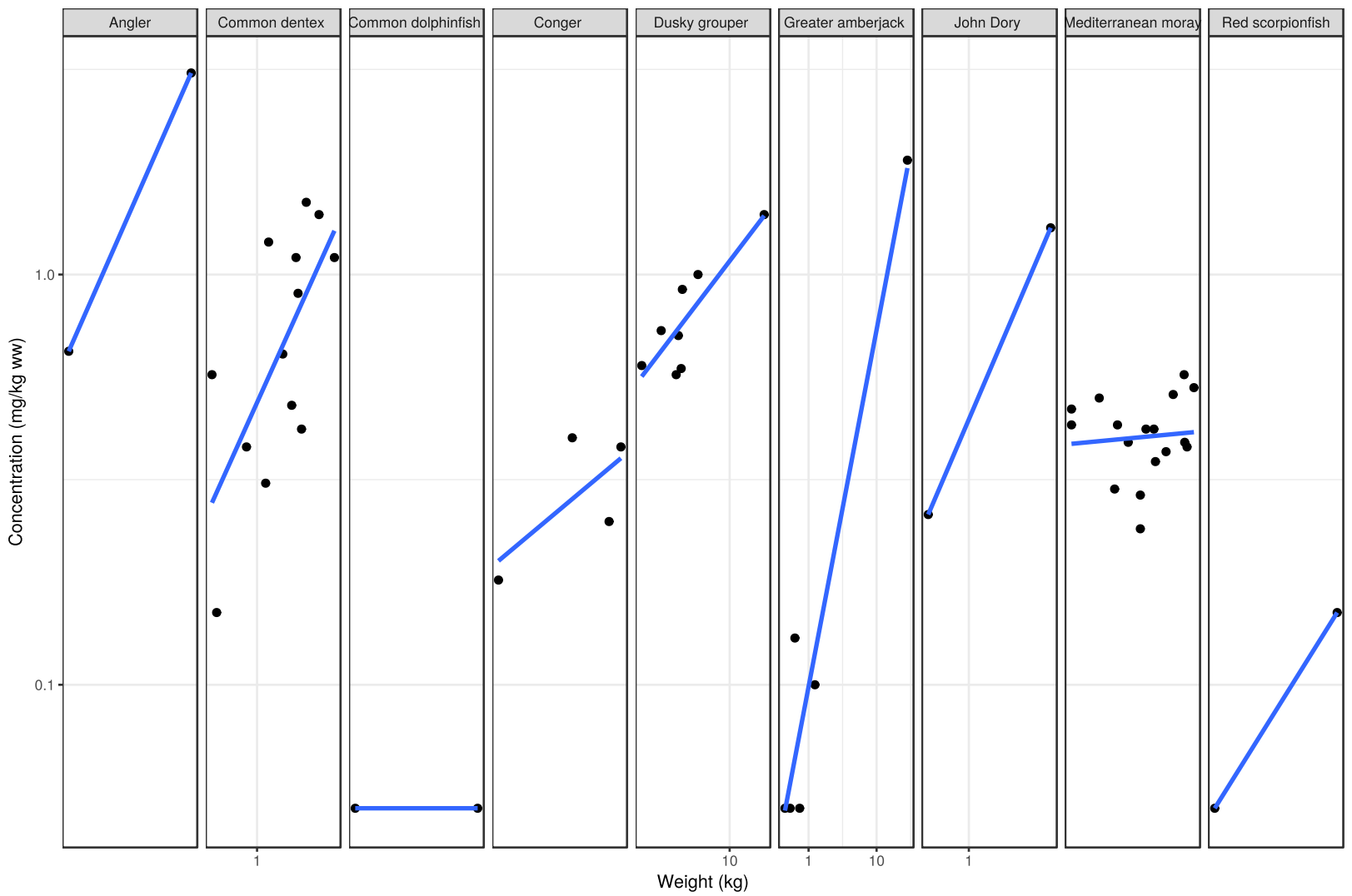

Fig. 6. Representation of the mercury concentrations vs. weight of the fish specimens in each species belonging to the third trophic level (see Fig. 4).

compounds with high bioaccumulation potential. In any case, the observed concentrations of organochlorine compounds were below the threshold recommended by the EU for human consumption.

The Hg concentrations were significantly higher in the dusky grouper specimens from the Mediterranean Sea than from the Atlantic Ocean. Forty-one percent of the specimens from the Mediterranean and $25 \%$ of the species from the Atlantic Ocean analysed in the present study showed $\mathrm{Hg}$ concentrations above the EU recommended limit for human consumption.

In the third trophic level, a significant dependence between median $\mathrm{Hg}$ concentrations and weight of each studied species was observed. This dependence also remained significant when representing the $\mathrm{Hg}$ concentrations vs. weight of each specimen. Plotting the Hg concentrations vs individual weight for each species again showed higher concentrations at higher weight in each species except for Mediterranean moray. Accordingly, the weight/size effect of the individuals was an important factor determining $\mathrm{Hg}$ accumulation in lean fish but the trend was modulated by a species effect.

The PTWIs of total Hg were higher than the thresholds recommended by EFSA for adults and children, $110 \%$ and 140\%, respectively, and the estimated PTWIs for MeHg corresponded to 310\% and $400 \%$ of the recommended threshold values. In contrast, the PTWI values for organochlorine compounds were much lower than those recommended.

\section{Acknowledgements}

We thank Francesc Riera and Antoni Maria Grau for their assistance in the species selection and sampling. Financial support has been received from the EU projects HEALS (FP7-ENV-2013- 603946), NEUROSOME (H2020-MSCA-ITN-2017 SEP-210411486) and IDEM (11.0661/2017/750680/SUB/ENV.C2). Financial support from the Spanish Ministry of Economy and Competitiveness through the Projects
Cuantox (CTM2015-71832-P) and Consolider-Redes (CTM201459111-REDC) is also acknowledged.

\section{References}

AESA, 2006. Agencia Española de Seguridad Alimentaria (AESA). Modelo de dieta española para la determinación de la exposición del consumidor a sustancias químicas. Ministerio de Sanidad y Consumo, Madrid (Spain) http://www.aecosan.msssi.gob. es/AECOSAN/docs/documentos/para_consumidor/modelo_dieta_espanola.pdf.

Aguilar, A., Borrell, A., 2005. DDT and PCB reduction in the western Mediterranean from 1987 to 2002, as shown by levels in striped dolphins (Stenella coeruleoalba). Mar. Environ. Res. 59, 391-404.

Álvarez-Pedrerol, M., Ribas-Fitó, N., Torrent, M., Carrizo, D., Garcia-Esteban, R., Grimalt J.O., Sunyer, J., 2008. Thyroid disruption at birth due to prenatal exposure to $\beta$ hexachlorocyclohexane. Environ. Int. 34, 737-740.

Arellano, L., Fernandez, P., Tatosova, J., Stuchlik, E., Grimalt, J.O., 2011. Long-range transported atmospheric pollutants in snowpacks accumulated at different altitudes in the Tatra Mountains (Slovakia). Environ. Sci. Technol. 45, 9268-9275.

Banana, A.S., Radin, Mohamed M.R., Al-Gheethi, A.A., 2016. Mercury pollution for marine environment at Farwa Island, Libya. J. Environ. Health Sci. Eng. 14, 5.

Berdie, L., Grimalt, J.O., 1998. Assessment of the sample handling procedures in a laborsaving method for the analysis of organochlorine compounds in a large number of fish samples. J. Chromatogr. 823, 373-380.

BOE, 2015. Resolución de 26 de febrero de 2015, de la Secretaría General de Pesca, por la que se publica el listado de denominaciones comerciales de especies pesqueras y de acuicultura admitidas en España. https://www.boe.es/boe/dias/2015/03/12/pdfs/ BOE-A-2015-2653.pdf https://www.boe.es/boe/dias/2015/03/12/pdfs/BOE-A-20152653.pdf.

Bonsignore, M., Salvagio Manta, D., Oliveri, E., Sprovieri, M., Basilone, G., Bonanno, A., Falco, F., Traina, A., Mazzola, S., 2013. Mercury in fishes from Augusta Bay (southern Italy): risk assessment and health implication. Food Chem. Toxicol. 56, 184-194.

Brambilla, G., Abete, M.C., Binato, G., Chiaravalle, E., Cossu, M., Dellatte, E., Miniero, R., Orletti, R., Piras, P., Roncarati, A., Ubaldi, A., Chessa, G., 2013. Mercury occurrence in Italia seafood from the Mediterranean Sea and possible intake scenarios of the Italian coastal population. Regul. Toxicol. Pharmacol. 65, 269-277.

Bravo, N., Hansen, S., Økland, I., Garí, M., Álvarez, M.V., Matiocevich, S., Odland, J.-Ø. Grimalt, J.O., 2017. Influence of maternal and sociodemographic characteristics on the accumulation of organohalogen compounds in Argentinian women. The EMASAR study. Environ. Res. 158, 759-767.

Calatayud, M., Devesa, V., Virsed, J.M., Barberá, R., Montoro, R., Vélez, D., 2012. Mercury and selenium in fish and shellfish: occurrence, bioaccessibility and uptake by Caco2 cells. Food Chem. Toxicol. 50, 2696-2702. 
Cano-Sancho, G., Perello, G., Maulvault, A.L., Marques, A., Nadal, M., Domingo, J.L., 2015 Oral bioaccessibility of arsenic, mercury and methylmercury in marine species commercialized in Catalonia (Spain) and health risks for the consumers. Food Chem. Toxicol. 86, 34-40.

Costa, O., Lopez-Espinosa, M.-J., Vizcaino, E., Murcia, M., Iñiguez, C., Navarrete-Muñoz E.M., Grimalt, J.O., Tardon, A., Ballester, F., Fernandez-Somoano, A., 2016. Dietary and household sources of prenatal exposure to polybrominated diphenyl ethers (PBDEs) in the INMA birth cohort (Spain). Environ. Sci. Technol. 50, 5935-5944.

Cresson, P., Fabri, M.C., Bouchoucha, M., Brach, C.P., Chavanona, F., Jadaud, A., Knoery, J., Miralles, F., Cossa, D., 2014. Mercury in organisms from the northwestern Mediterranean slope: importance of food sources. Sci. Total Environ. 497-498, 229-238.

DOUE, 2011. Reglamento (UE) No 1259/2011 de la comisión de 2 de diciembre de 2011 por el que se modifica el Reglamento (CE) no 1881/2006 en lo relativo a los contenidos máximos de dioxinas, PCB similares a las dioxinas y PCB no similares a las dioxinas en los productos alimenticios. http://coli.usal.es/web/criterios/criterios micro/limites_contam/pdf/12_59_2012.pdf.

EFSA, 2012. Scientific opinion on the risk for public health related to the presence of mercury and methylmercury in food. EFSA J. 10, 2985-3226.

EFSA, 2015. The EFSA comprehensive European food consumption database. http://www. efsa.europa.eu/en/food-consumption/comprehensive-database.

European Commission, 2006. Commission Regulation No. 1881/2006, setting maximum levels for certain contaminants in foodstuffs. Off. J. Eur. Communities L364, 5

Falcó, G., Bocio, A., Llobet, J.M., Domingo, J.L., Casas, C., Teixidó, A., 2004. Dietary intake of hexachlorobenzene in Catalonia, Spain. Sci. Total Environ. 322, 63-70.

Falcó, G., Llobet, J.M., Bocio, A., Domingo, J.L., 2006. Daily intake of arsenic, cadmium, mercury, and lead by consumption of edible marine species. J. Agric. Food Chem. 54, 6106-6112.

Forns, J., Lertxundi, N., Aranbarri, A., Murcia, M., Gascon, M., Martinez, D., Grellier, J., Lertxundi, A., Julvez, J., Fano, E., Goñi, F., Grimalt, J.O., Ballester, F., Sunyer, J. Ibarluzea, J., 2012. Prenatal exposure to organochlorine compounds and neuropsychological development up to two years of life. Environ. Int. 45, 72-77.

Freire, C., Ramos, R., Lopez-Espinosa, M.-J., Díez, S., Vioque, J., Ballester, F., Fernández, M.F., 2010. Hair mercury levels, fish consumption, and cognitive development in preschool children from Granada, Spain. Environ. Res. 110, 96-104.

Garí, M., Grimalt, J.O., Torrent, M., Sunyer, J., 2013. Influence of socio-demographic and diet determinants on the levels of mercury in preschool children from a Mediterranean island. Environ. Pollut. 182, 291-298

Gascon, M., Vrijheid, M., Martınez, D., Ballester, F., Basterrechea, M., Blarduni, E. Esplugues, A., Vizcaino, E., Grimalt, J.O., Morales, E., Sunyer, J., On behalf of the Infancia y Medio Ambiente (Environment and Childhood) (INMA) project, 2012 Pre-natal exposure to dichlorodiphenyldichloroethylene and infant lower respiratory tract infections and wheeze. Eur. Respir. J. 39, 1188-1196.

Gascon, M., Verner, M.-A., Guxens, M., Grimalt, J.O., Forns, J., Ibarluzea, J., Lertxundi, N. Ballester, F., Llop, S., Haddad, S., Sunyer, J., Vrijheid, M., 2013. Evaluating the neurotoxic effects of lactational exposure to persistent organic pollutants (POPs) in Spanish children. Neurotoxicology 34, 9-15.

Gillespie, B.W., Chen, Q., Reichert, H., Franzblau, A., Hedgeman, E., Lepkowski, J., Adriaens P., Demond, A., Luksemburg, l., Garabrant, D.H., 2010. Estimating population distributions when some data are below a limit of detection by using a reverse Kaplan-Meier estimator. Epidemiology 21, S64-S70.

Government of Spain, 2012. Principales Especies Pesqueras de Interés Comercial. http:/ www.alimentacion.es/imagenes/es/Cartel\%2030_principales_especies_48x68\%20_ tcm8-19058.pdf

Grandjean, P., Weihe, P., White, R.F., Debes, F., Araki, S., Yokoyama, K., Murata, K., Sørensen, N., Dahl, R., Jørgensen, P.J., 1997. Cognitive deficit in 7-year-old children with prenatal exposure to methylmercury. Neurotoxicol. Teratol. 19, 417-428.

Grimalt, J.O. Sunyer, J., Moreno, V., Amaral, O.C., Sala, M., Rosell, A., Antó, J.M., Albaigés, J. 1994. Risk excess of soft-tissue sarcoma and thyroid cancer in a community exposed to airborne organochlorinated compound mixtures with a high hexachlorobenzene content. Int. J. Cancer 56, 200-203.

Harada, M., 1995. Minamata disease: methylmercury poisoning in Japan caused by environmental pollution. Crit. Rev. Toxicol. 25, 1-24.

Howsam, M., Grimalt, J.O., Guino, E., Navarro, M., Marti-Rague, J., Peinado, M.A., Capella, G., Moreno, V., 2004. Organochlorine exposure and colorectal cancer risk. Environ. Health Perspect. 112, 1460-1466.

JMPR, 2000. Joint FAO/WHO meetings on pesticide residues 2000. Expert Committee on Food Additives, FAO Plant Production and Protection Paper 163/59, Rome, 2001Report NMRS 29/TRS 220-JECFA 5/28.

Junqué, E., Garí, M., Arce, A., Torrent, M., Sunyer, J., Grimalt, J.O., 2017. Integrated assessment of infant exposure to persistent organic pollutants and mercury via dietary intake in a central western Mediterranean site (Menorca Island). Environ. Res. 156, 714-724.

Karagas, M.R., Choi, A.L., Oken, E., Horvat, M., Schoeny, R., Kamai, E., Cowell, W. Grandjean, P., Korrick, S., 2012. Evidence on the human health effects of low-level methylmercury exposure. Environ. Health Perspect. 120, 799-806.

Kljakovic-Gaspic, Z., Herceg, S.R., Klincic, D., Ticina, V., 2015. Chlorinated compounds in the muscle tissue of fish from the Croatian Adriatic: preliminary data on contamination and the associated health risks. Arh. Hig. Rada. Toksikol. 66, 299-308.

Koenig, S., Solé, M., Fernández-Gómez, C., Díez, S., 2013. New insights into mercury bioaccumulation in deep-sea organisms from the NW Mediterranean and their human health implications. Sci. Total Environ. 442, 329-335.

Krauthacker, B., Votava-Raic, A., Romanic, S.C., Tjesic-Drinkovic, D., Tjesic-Drinkovic, D., Reiner, E., 2009. Persistent organochlorine compounds in human milk collected in Croatia over two decades. Arch. Environ. Contam. Toxicol. 57, 616-622.

Lamborg, C.H., Hammerschmidt, C.R., Bowman, K.L., Swarr, G.J., Munson, K.M., Ohnemus, D.C., Lam, P.J., Heimbürger, L.E., Rijkenberg, M.J.A., Saito, M.A., 2014. A global ocean inventory of anthropogenic mercury based on water column measurements. Nature $512,65-68$

Llobet, J.M., Falcó, G., Casa, C., Teixidó, A., Domingo, J.L., 2003. Concentration of arsenic, cadmium, mercury, and lead in common foods and estimated daily intake by children, adolescents, adluts, and seniors of Catalonia, Spain. J. Agric. Food Chem. 51, 838-842.

Llop, S., Ballester, F., Vizcaino, E., Murcia, M., Lopez-Espinosa, M.J., Rebagliato, M., Vioque, J., Marco, A., Grimalt, J.O., 2010. Concentrations and determinants of organochlorine levels among pregnant women in Eastern Spain. Sci. Total Environ. 408, 5758-5767.

Llop, S., Murcia, M., Aguinagalde, X., Vioque, J., Rebagliato, M., Cases, A., Iñiguez, C., LopezEspinosa, M.J., Amurrio, A., Navarrete-Muñoz, E.M., Ballester, F., 2014. Exposure to mercury among Spanish preschool children: trend from birth to age four. Environ. Res. 132, 83-92.

Llull, R.M., Garí, M., Canals, M., Rey-Maquieira, T., Grimalt, J.O., 2017. Mercury concentrations in lean fish from the Western Mediterranean Sea: dietary exposure and risk assessment in the population of the Balearic Islands. Environ. Res. 158, 16-32.

Martí-Cid, R., Huertas, D., Nadal, M., Linares, V., Schuhmacher, M., Grimalt, J.O., Domingo, J.L., 2010. Dietary exposure to organochlorine compounds in Tarragona Province (Catalonia, Spain): health risks. Hum. Ecol. Risk. Assess. 16, 588-602.

Mihats, D., Moche, W., Prean, M., Rauscher-Gabernig, E., 2015. Dietary exposure to nondioxin-like PCBs of different population groups in Austria. Chemosphere 126, 53-59.

Morales, E., Sunyer, J., Castro-Giner, F., Estivill, X., Julvez, J., Ribas-Fitó, N., Torrent, M., Grimalt, J.O., de Cid, R., 2008. Influence of glutathione S-transferase polymorphisms on cognitive functioning effects induced by p,p'-DDT among preschoolers. Environ. Health Perspect. 116, 1581-1585.

Murata, K., Budtz-Jørgensen, E., Grandjean, P., 2002. Benchmark dose calculations for methylmercury-associated delays on evoked potential latencies in two cohorts of children. Risk Anal. 22, 465-474.

Myers, G.J., Davidson, P.W., Cox, C., Shamlaye, C., Cernichiari, E., Clarkson, T.W., 2000. Twenty-seven years studying the human neurotoxicity of methylmercury exposure. Environ. Res. 83, 275-285.

Naccari, C., Cicero, N., Ferrantelli, V., Giangrosso, G., Vella, A., Macaluso, A., Naccari, F., Dugo, G., 2015. Toxic metals in pelagic, benthic and demersal fish species from Mediterranean FAO zone 37. Bull. Environ. Contam. Toxicol. 95, 567-573.

Obeid, P.J., Fares, S.A., Farhat, G.N., El-Khoury, B., Nassif, R.M., El-Nakat, J., Dhaini, H.R., 2017. Mercury health risk assessment among a young adult Lebanese population. Environ. Sci. Pollut. Res. 24, 9370-9378.

Olmedo, P., Pla, A., Hernández, A.F., Barbier, F., Ayouni, L., Gil, F., 2013. Determination of toxic elements (mercury, cadmium, lead, tin and arsenic) in fish and shellfish samples. Risk assessment for the consumers. Environ. Int. 59, 63-72.

Perello, G., Llobet, J.M., Gómez-Catalán, J., Castell, V., Centrich, F., Nadal, M., Domingo, J.L., 2014. Human health risks derived from dietary exposure to toxic metals in Catalonia, Spain: temporal trends. Biol. Trace Elem. Res. 162, 26-37.

Polder, A., Savinova, T.N., Tkachev, A., Loken, K.B., Odland, J.O., Skaare, J.U., 2010. Levels and patterns of persistent organic pollutants (POPS) in selected food items from Northwest Russia (1998-2002) and implications for dietary exposure. Sci. Total Environ. 408, 5352-5361.

Porta, M., Malats, N., Jariod, M., Grimalt, J.O., Rifà, J., Carrato, A., Guarner, L., Salas, A., SantiagoSilva, M., Corominas, J.M., Andreu, M., Real, F.X., 1999. Serum levels of organochlorine compounds and K-ras mutations in exocrine pancreatic cancer. Lancet 354, 2125-2129.

Qian, Zhuozhen, Luo, Fangfang, Wu, Chengye, Zhao, Ran, Cheng, Xuan, Qin, Wenfeng 2017. Indicator polychlorinated biphenyls (PCBs) and organochlorine pesticides (OCPs) in seafood from Xiamen (China): levels, distributions, and risk assessment. Environ. Sci. Pollut. Res. 24, 10443-10453.

R Core Team, 2015. R: A language and environment for statistical computing. R Foundation for Statistical Computing, Vienna, Austria https://www.R-project.org/.

Ribas-Fito, N., Torrent, M., Carrizo, D., Muñoz-Ortiz, L., Julvez, J., Grimalt, J.O., Sunyer, J., 2006. In Utero Exposure to Background Concentrations of DDT and Cognitive Functioning among Preschoolers. Am. J. Epidemiol. 164 (2006), 955-962.

Ribas-Fitó, N., Júlvez, J., Torrent, M., Grimalt, J.O., Sunyer, J., 2007. Beneficial effects of breastfeeding on cognition regardless of DDT concentrations at birth. Am. J. Epidemiol. 166, 1198-1202.

Riera, F., Oliver, J., Terrassa, J., 1995. Peixos de Les Balears. Conselleria d'Obres Públiques i Ordenació del Territori, Palma de Mallorca (261 pp. Isbn 84-606-2604-0).

Rodríguez-Hernández, A. Camacho, M. Henríquez-Hernández, LA. Boada, L.D., RuizSuárez, N., Valerón, P.F., Almeida, M.G., Zaccaroni, A., Zumbado, M., Luzardo, O.P., 2016. Assessment of human health hazards associated with the dietary exposure to organic and inorganic contaminants through the consumption of fishery products in Spain. Sci. Total Environ. 557-558, 808-818.

Sala, M., Sunyer, J., Herrero, C., To-Figueras, J., Grimalt, J.O., 2001. Association between serum concentration of hexachlorobenzene and polychlorobiphenyls with thyroid hormone and liver enzymes in a sample of the general population. Occup. Environ. Med. 58, 172-177.

SMAP, 2015. Serveis de millora agrarian i pesquera. www.caib.es/sites/semilla/ca/taules i_grafics_2015.

Smink, A., Ribas-Fito, N., Garcia, R., Torrent, M., Mendez, M.A., Grimalt, J.O., Sunyer, J., 2008. Exposure to hexachlorobenzene during pregnancy increases the risk of overweight in children aged 6 years. Acta Paediatr. 97, 1465-1469.

Storelli, M.M., Barone, G., 2013. Toxic metals (Hg, Pb, and Cd) in commercially important demersal fish from Mediterranean Sea: contamination levels and dietary exposure assessment. J. Food Sci. 78, 362-366.

Storelli, M.M., Giacominelli-Stuffler, R., Marcotrigiano, G., 2002. Mercury accumulation and speciation in muscle tissue of different species of sharks from Mediterranean Sea, Italy. Bull. Environ. Contam. Toxicol. 68, 201-210.

Storelli, M.M., Barone, G., Piscitelli, G., Marcotrigiano, G.O., 2007. Mercury in fish: concentration vs. fish size and estimates of mercury intake. Food Addit. Contam. 24, $1353-1357$ 
Sunyer, J., Torrent, M., Garcia-Esteban, R., Ribas-Fitó, N., Carrizo, D., Romieu, I., Antó, J.M. Grimalt, J.O., 2006. Early exposure to dichlorodiphenyldichloroethylene, breastfeeding and asthma at age six. Clin. Exp. Allergy 36, 1236-1241.

Sunyer, J., Alvarez-Pedrerol, M., To-Figueras, J., Ribas-Fitó, N., Grimalt, J.O., Herrero, C., 2008. Urinary porphyrin excretion in children is associated with exposure to organochlorine compounds. Environ. Health Perspect. 116, 1407-1410.

Törnkvist, A., Glynn, A., Aune, M., Darnerud, P.O., Ankarberg, E.H., 2011. PCDD/F, PCB, PBDE, HBCD and chlorinated pesticides in a Swedish market basket from 2005-levels and dietary intake estimations. Chemosphere 83, 193-199.

Torres, J., Eira, C., Miquel, J., Ferrer-Maza, D., Delgado, E., Casadevall, M., 2015. Effect of intestinal tapeworm Clestobothrium crassiceps on concentrations of toxic elements and selenium in European hake merluccius merluccius from the Gulf of lion (northwestern Mediterranean Sea). J. Agric. Food Chem. 63, 9349-9356.

Valvi, D., Mendez, M.A., Martinez, D., Grimalt, J.O., Torrent, M., Sunyer, J., Vrijheid, M., 2012. Prenatal concentrations of polychlorinated biphenyls, DDE, and DDT and overweight in children: a prospective birth cohort study. Environ. Health Perspect. 120, 451-457.

Vázquez, M., Calatayud, M., Jadán, M., Chiocchetti, G., Vélez, D., Devesa, V., 2015. Toxic trace elements at gastrointestinal level. Food Chem. Toxicol. 2015, 163-175.

Verhaert, V., Newmark, N., D'Hollander, W., Covaci, A., Vlok, W., Wepener, V., AddoBediako, A., Jooste, A., Teuchies, J., Blust, R., Bervoets, L., 2017. Persistent organic pollutants in the Olifants River basin, South Africa: bioaccumulation and trophic transfer through a subtropical aquatic food web. Sci. Total Environ. 586, 792-806.

Vives, I., Grimalt, J.O., 2002. A method for integrated analysis of polycyclic aromatic hydrocarbons and organochlorine compounds in fish liver. J. Chromatogr. B 768, 247-254.
Vizcaino, E., Grimalt, J.O., Glomstad, B., Fernández-Somoano, A., Tardón, A., 2014. Gestational weight gain and exposure of newborns to persistent organic pollutants. Environ. Health Perspect. 122, 873-879.

Wiener, J.G., Bodaly, R.A., Brown, S.S., Lucotte, M., Newman, M.C., Porcella, D.B., et al., 2007. Monitoring and evaluating trends in methylmercury accumulation in aquatic biota. In: Harris, R., Krabbenhoft, D.P., Mason, R., Murray, M.W., Reash, R., Saltman, T. (Eds.), Ecosystem Responses to Mercury Contamination: Indicators of Change. CRC Press, Pensacola, FL, pp. 87-122.

World Health Organization - International Programme on Chemical Safety (WHO-IPCS), 1990. Methylmercury. Environmental Health Criteria 101 Geneva, Switzerland http://www.inchem.org/documents/ehc/ehc/ehc101.htm, Accessed date: 26 January 2013.

Xu, F., Tay, J., Covaci, A., Padilla-Sánchez, J., Papadopoulou, E., Haug, L., Neels, H., Sellström, U., Wit, C., 2017. Assessment of dietary exposure to organohalogen contaminants, legacy and emerging flame retardants in a Norwegian cohort. Environ. Int. 102, 236-243.

Yabanli, M., Alparslan, Y., 2015. Potential health hazard assessment in terms of some heavy metals determined in demersal fishes caught in eastern Aegean Sea. Bull. Environ. Contam. Toxicol. 95, 494-498.

Yusa, V., Suelves, T., Ruiz-Atienza, L., Cervera, M.L., Benedito, V., Pastor, A., 2008. Monitoring programme on cadmium, lead and mercury in fish and seafood from Valencia, Spain: levels and estimated weekly intake. Food Addit. Contam. Part B Surveill. 1, 22-31. 